\title{
BUilding Social ResilienCE ON ASMAt PEOPLE: Social AND Cultural Perspective
}

\author{
Cahyo Pamungkas \\ Lembaga Ilmu Pengetahuan Indonesia \\ J1. Gatot Subroto Kav. 10, Jakarta 12720, Indonesia \\ cahyopamungkas@gmail.com
}

Received: 13/02/2018; revisions: 03/03 - 09/06/2018; accepted: 11/06/2018

Published online: 31/07/2018

\begin{abstract}
Various studies on Asmat ethnicities tend to focus on carving art and cultural richness of wood. Since the malnutrition and measles affecting children under five in this area from September 2017 to mid January 2018 has opened the eyes of international communities that the sustainability of Asmat tribe is questioned. Various scientific analyzes explain that the mass death of children resulted from low health culture, the less supportive environment, and the difficulty of providing health services to isolated areas. It implicitly says that the people, culture, and environment of Asmat tribes are the main causes of this disease. It is as if the Asmat people and culture and the geographical situation are the cause of this disease. Therefore, this article aims to describe the epidemic from a social and cultural perspective, namely the low social resilience of the Asmat. The research method is conducted by using literature studies and a focused discussion in Jayapura. The theoretical framework used is the ecological and cultural approach to viewing the sustainability of a community to be able to cope with environmental change. The argument of this study is to save Asmat tribes in the extended period only by restoring them to their habitat and reducing the dependence on the food consumption provided by the market. Results of this study indicate that the underlying cause of Asmat outbreaks is the gratuity of Asmat people from their ecological habitats so that they depend on the food provided by the market.
\end{abstract}

Keywords: Asmat People; Social Resilience; Cultural Perspectives; Sustainability

\section{INTRODUCTION}

Asmat tribe is mostly settled in Asmat district, the southern part of Papua Province, between Merauke and Mimika Regency. They are estimated to number of 70,000 residents who occupy 120 villages covering 20,200 km² (Rollings, 2010: 17). This district constitutes swamp land (80\%) and dry land (20\%). The land in this area is constantly damp throughout the year and is dominated by a $50 \mathrm{~cm}$ puddle for three months during rainy season (Prasetya, 2013: 24). In general, the residents of Asmat live by the rivers that all flow into the Arafuru Sea. At high tide, when the sea water rises to the river, the Asmat tribe can traverse the river up to the inland approximately $50 \mathrm{~km}$. Among these rivers, there is almost entirely swamps land that is difficult to cultivate for agriculture or plantations. In the past, they consume food from sago trees that naturally grow in the swamps. In addition, Asmat tribes also hunt to catch wild boars, cassowaries, cuscus, birds, fish, and shrimp.
Cassowary is the main source of protein for Asmat people (Rahawarin et al., 2014: 99). The residence is almost unapproachable and can only be reached during the high tide, that it is isolated from the outside world. This area is now open due to expeditionary activities and missionaries in the colonial period, as well as expansion of timber company investment.

Asmat tribe became well-known throughout the archipelago and the world due to the progress of art of carving (Eskak, 2016; Rahajaan, 2012). The art of carving is stored in various museums and promoted through various international cultural fairs. Asmat culture is known as wooden culture as they use trees to survive. The vegetation in the forest is considered as symbols that resemble groups of Asmat people, which have the power to withstand the weather and difficult climate (Maryone, 2011). Wood is used to build houses and construct road infrastructure between one house to another. Wood is also used as a carving material to reflect on their thoughts on spiritual life and the spirit of 


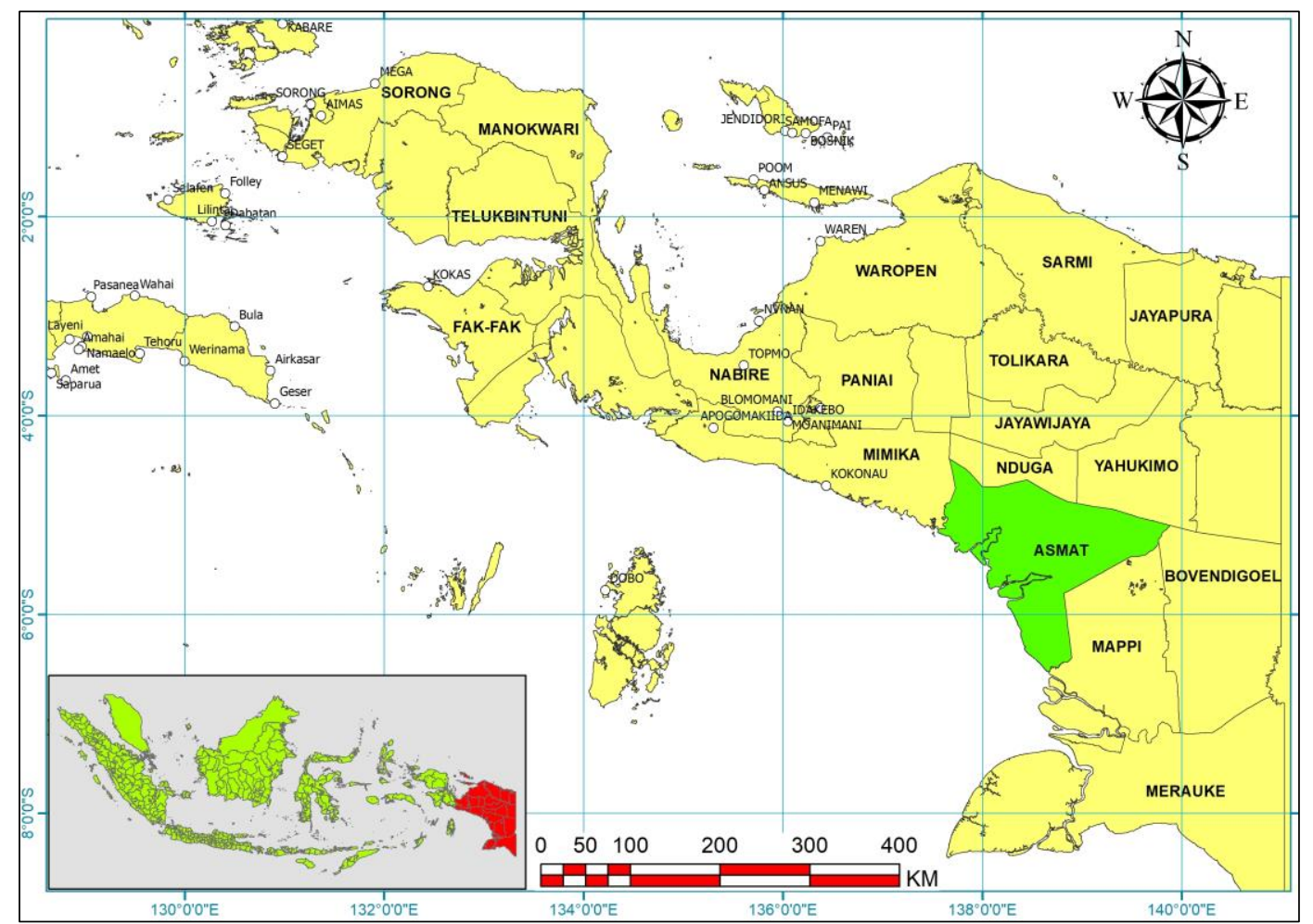

Figure 1. Location of Asmat District

(Source: Modified from basemap of Badan Informasi Geospasial, 2018)

their ancestors as well as magical powers. In the past, Asmat wood carving was a personification of their ancestral spirits and employed as a medium in ritual ceremonies (Asmarandani, 2007: 20). In fact, the tree is philosophically depicted as a living man with legs and hands and spirit (Budisantosa et al., 1986; Hidayah, 2015).

The renowned Asmat tribe in various parts of the world with its woodcarving expertise, it is now known for its measles and malnutrition. Online media Kompas.com (Purba, January 15, 2018) reported in midJanuary 2018, the mass death of children under the age of five in this area. As many as 71 children under the age of five died of measles and malnutrition. Since then, Asmat, once known as one of the tribes in Papua who has the ability in the art of carving, is now vulnerable tribe in its sustainability. The Antara News Agency reported earlier that in September 2017, measles and malnutrition left 68 children under the age of five died in this area. However, the Government has not paid serious attention as it has not been widely reported. In January 2018, the Antara News Agency reported that 393 under the age of five underwent outpatient treatment and 175 inpatients, making this case an Extraordinary Incident (KLB) by the Central Government (Apinino, January 31, 2018). Related to the matter, this article intends to answer the following questions: (i) How is the description of malnutrition problem in Asmat District? (ii) How is the strategy of building social resilience of Asmat people in the future? And (iii) What kind of solutions are needed to help the Asmat people go on living?

\section{Methods}

This article is the result of independent research conducted by Indonesian Institute of Sciences or Lembaga Ilmu Pengetahuan Indonesia (LIPI), Jakarta. Sources of information were obtained from the tracking of secondary data in national mass media, reports of explorative meetings organized by LIPI and the Papua Peace Network of Jaringan Damai Papua (JDP). The primary source was obtained from the author's observation in Jayapura on January 31, 2018, when attending Papua Lawyers Club (PLC) in Jaya TV. A number of books and journals were employed to formulate the concepts used in this study that is social resilience. The analytical method used descriptive analysis, i.e. the field findings related to Extraordinary Incident (KLB) of malnutrition and measles that occurred in Asmat Regency were analyzed with the theory of social resilience. The argument was built to save the Asmat tribe in the long term only by improving their social resilience by revitalizing their traditional life and reducing dependence on others.

One definition of the ethnic group in Anthropology according to Narrol (1964. Cf. Barth, 1969) is having the ability to multiply. Therefore, sustainability is one of the prerequisites that an ethnic group must have. This concept is closely related to resilience because in order 
to carry on, a social group must be able to have the ability to survive and adapt to its environment. Social resilience is one of the most popular concepts in ecology and is used as a means of analysis by social science reviewers to perceive the endurance of a community. Further explored, this concept is rooted in ecology, but is still relevant in social studies, such as adaptation strategies and environmental change. One of the main literature in this concept is Adger (2000) which explained social resilience as the ability of a social group to adapt to changes outside and within its community. This ability is a prerequisite for a community to carry on its life. In social ecology, we often notice external changes, such as natural disasters, therefore a community must be able to adapt to outside interference and maintain the existing social structures and processes within the community.

The implication of this definition is that social resilience is shaped by its changing external environment and the ability of the community to manage its inherent capital. In addition to external changes, social resilience also has an internal dimension, namely the ability to resolve internal problems within the community. Another social resilience expert, Sonn \& Fisher (1988) explained that the capacity of a community to survive is its power to resolve both external and internal issues. The same is true of Bishop \& Syme (1996) that internal conflict management is a key requirement for the community to survive the changes. Chaskin et al. (2001) stated that the capacity of the community can be established and developed through interaction among community members, organizational resources, and social capital. They can be employed to solve common problems, which is to materialize the progress, safety, and sustainability of their communities. In praxis, all three can be perceived through: community resources, a number of active social actors and collective actions that have strategic value.

Social resilience in the macro, social ecology perspective is a social process that is inseparable from the dialectical correlation between environmental change and the ability of the community. Social resilience has nothing to do with something given from the outside but it can be grown from within and shaped by its external experience. Keck and Sakdapolrak (2013) stated that the three dimensions of social resilience include the ability to cope with external change, study past experiences and use them in the future. It is shaped by social networks and relations, power relations and constructs of knowledge. In the context of the Asmat people, all three are essential for this community to continue to exist and should utilize: a number of social ties between members of the community, having a strategic position in the region and maintain local wisdom gained from the past. Social capital by social resilience reviewers is considered as a determinant factor for dealing with an uncertain future (Adger, 2000).

A new stream in the theory of social resilience does not only emphasize ecological endurance of the community, but from cultural perspective. In this new perspective, Kirmayer et al. (2008) explained that social resilience is regarded as the whole process of development and transformation of a community and its culture, the whole individuals along with its social structure, and the linkage between social actors and their power relations with other social actors. In contrast to social ecologists, Kirmayer places social resilience in the cultural center point. It also includes a growing spiritual and cultural dimension within a community. Both are keys for a community to endure amid its external changes. Thus, social resilience can be regarded by its sustainability of the life cycle, transmission of traditions and cultural values, inheritance of knowledge about the culture connecting members of the community with the history of the community. This view is also stated by Gunnestad (2003; 2006) which places value, meaning, and trust as the central point of social resilience.

In the context of Asmat, the cultural aspect as an element of social resilience can be viewed from its local wisdom in daily life. Local wisdom is nothing but an accumulation of experience and learning that goes on continuously and inherited from generation to generation (Kamun et al., 2010: 161). For example, when members of the tribe group respond to climate change then they do so based on the understanding, experience and knowledge that the previous generation had taught. Local wisdom includes inherited traditions and knowledge, containing cultural values of previous generations. As a result, it also serves as a bridge that can attach the past with the present, or become a multigeneration bonding node (Kamun et al., 2010: 161).

\section{RESULT AND DISCUSSION}

\section{Problems of Malnutrition and Measles}

The problem of malnutrition and measles has occurred since 2015 in Papua (International Coalition for West Papua (ICP), 2017). This outbreak occurs with the same pattern and recurs every year as follows (Papua Lawyers Club, January 31, 2018). ${ }^{\mathrm{i}}$ This incident generally occurs in isolated areas such as Nduga, Deyai, Yahukimo, and Asmat. Ironically, those who report first are not from the Community Health Center (Puskesmas) or local government, but by churches or nongovernmental organizations. This indicates that coordination of the government has not worked optimally in Papua. In terms of health services, paramedics in the area are not evenly distributed and 
health officials are partly non-medicals as the implications of local politics.

Some analyzes are expanding, both within the Government or the community. For example, Father John Jonga, one of the priests in Wamena, in the Papua Lawyers Club event in Jayapura (January 31, 2018) argued that the Asmat outbreak case reflects the absence of the state in the suffering of Papuans. This denotes that some citizens do not use the outcomes of development and prosperity. Moreover, communities hardly receive adequate nutrition for sustainability (Rahadian, February 1, 2018). There is still a lot of perception of life situation in Asmat. In fact, President Jokowi proposed the relocation of people affected by measles and malnutrition from villages to sterile areas. The relocation of malnourished victims from villages to towns in both the capital district and capital regency is planned for them to be easily accessible by the healthcare unit. This offer was submitted by President Jokowi to the Governor of Papua and the Regent of Asmat since measles and malnutrition always infected people living in remote areas. This plan arises as the health care units often cannot reach isolated areas as a result of transportation difficulties. In addition, Asmat residents spread to various parts of the country, thus it increases the difficulties for health units to serve them. Not to mention, many Asmat residents moved or worked in the forest that making it impossible to reach them when the health unit visited the village. In order to reach the villages from the capital district, it takes an average of 3 hours at a cost of 3 to 4 million rupiahs (Ihsanuddin, January 23, 2018).

Having recognized further, however in reality, this relocation will take more lives of Asmat people as it is tantamount to depriving them of their cultural roots and habitat like Amungme people uprooted from Tembagapura. On the other hand, a number of activists in Papua, especially those based in Jayapura alleged that

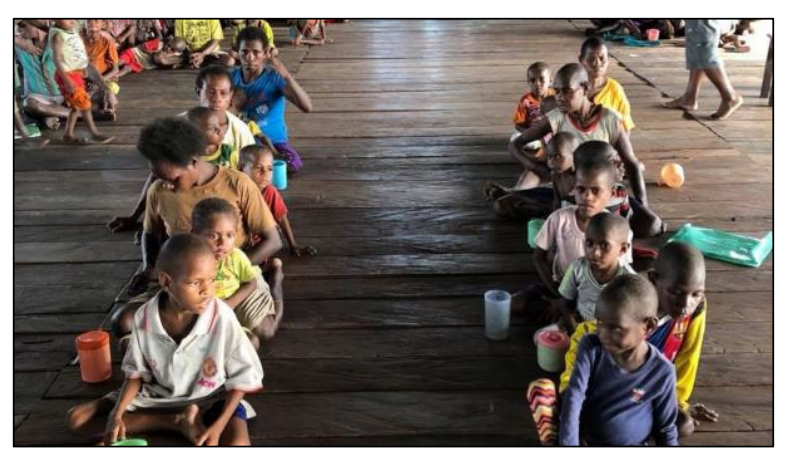

Figure 2. Many of the children were never immunised or given basic healthcare

(Source: Vaessen/Al Jazeera, 2018)

this outbreak was made up from the politics of state neglect for the suffering of the Papuans without fully perceiving the reality. National media, on the other hand, stated that natural conditions, as well as lack of infrastructure development as one of the causes of outbreaks, cannot be handled properly. This view suggests an increase in the construction of roads and bridges to penetrate transportation access to villages in this area (Rangga, 2018).

There are many versions refer to why this outbreak occurred in Asmat or other areas in Tanah Papua. According to the perspective of the Central Government, represented by the Ministry of Health, this case can occur not only health issues but also as a consequence of unresolved issues such as: unworthy living environment, community health and cultural behavior, low food security and limited infrastructure (Puspita, January 29, 2018). Environmental and cultural issues seem to be a complicated issue. Asmat residents mostly settle in swamp areas, in general, it is an estuary filled with water that during high tide, the water in the swamp will rise over their houses. Definitely, the increase of swamp water to the housings area will be accompanied by the spread of various types of germs. The availability of food

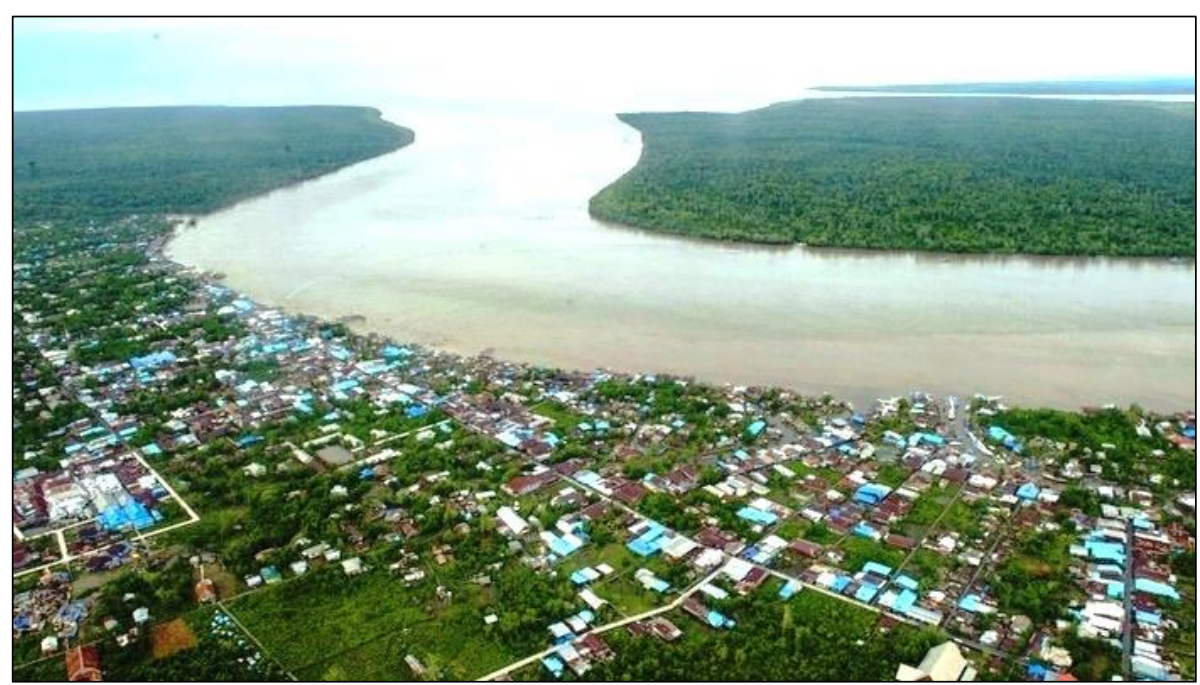

Figure 3. Aerial photos of houses over swamps and rivers in Agats City, Asmat District, Papua, Monday (29/1/18) (Source: Antara/M. Agung Rajasa, 2018) 
for example, Asmat people only consume tubers or sago that they have cultivated themselves. Infrastructure of the hospital is not feasible as it only provides inpatient spaces without adequate water and electricity. The short of adequate transportation infrastructure, which is rivers transportation, causes Asmat communities impossible to reach from the city of Agats. Environmental issues can also be viewed from the lack of sanitation and sufficient clean water for the community to live as the river water is quite brackish. This causes the community to rely on rainwater. Meanwhile, in order to dig wells, it needs a depth of 300 meters which would require a fairly expensive cost. This is exacerbated by the low attention of the Provincial and District Governments of Papua and West Papua to this condition, quite ironically with the availability of Special Autonomy funds that the Central Government delivers annually to the Provincial and Regency Governments (Puspita, January 29, 2018).

The Government's views need to be carefully examined in view of why the disease has recently emerged and has not occurred in the past. The statement is the mainstream opinion of the Center or the modern world that seems to blame traditional Asmat community life. If it is a matter of residence, the Asmat lives from one forest to another along the river. They have a hunting and gathering tradition that is the center of their culture. Living by the estuary or close to the river stream makes them easier to move along by their traditional boats. The environment cannot be held responsible as most of the Asmat Regency is soaked swamps and very little dry plains like in Merauke. Sago that has been consumable in the past is also part of the culture of consumption in Papua by their ancestors. There has never been any research explaining that consumption of sago or tubers leads the Papuans to become vulnerable to any disease. Likewise, limited infrastructure has occurred since Dutch era to this date. Nevertheless, the disease is more rapidly transmissible and spread in the present.
Therefore, it is necessary to examine the underlying causes of measles and malnutrition basically in the Papuan cultural perspective.

According to Father Rangga (2018), there are two aspects that can be used to explain why cases of measles and malnutrition can occur in Asmat communities. The main dimension is the change in people's lifestyle in terms of consumption. As having described in the introduction, Asmat tribe consumed forest products through hunting wild boar or cassowary in the past. Others were catching fish and various river products. Afterall, the main food is sago as main source of carbohydrates that thrives naturally in the forests and swamps. Hunting and living on the move allows them to adapt to the swampy nature. At times, it has never been heard of news or notes from evangelists about malnutrition and other diseases except the malaria epidemic. From time to time, the gathering society relies on its wealth of ecology. Following the implementation of Special Autonomy (Otsus), however, which is marked by the swift grants from Central and provincial to district and villages, their pattern of life and way of consumption has changed. With an abundance of grants, they are no longer working hard as all their basic needs are provided by the market and outside traders reaching the villages. They begin to consume various food commodities provided by the market (Vaessen, 2018, January 27).

There has been a shift from hunting and gathering to becoming dependent on disbursement of government subsidies that their resilience grows weaker in the face of environmental change. For instance, following the disbursement of village funds, people will choose to buy ready-made food that the traders brought, and they no longer catch fish or hunt in the forest. The availability of abundant money makes them easier to live, simply buying their food and clothing directly. Most Asmat people have already consumed raskin (rice for the underprivilegeds) and no longer cultivate sago that

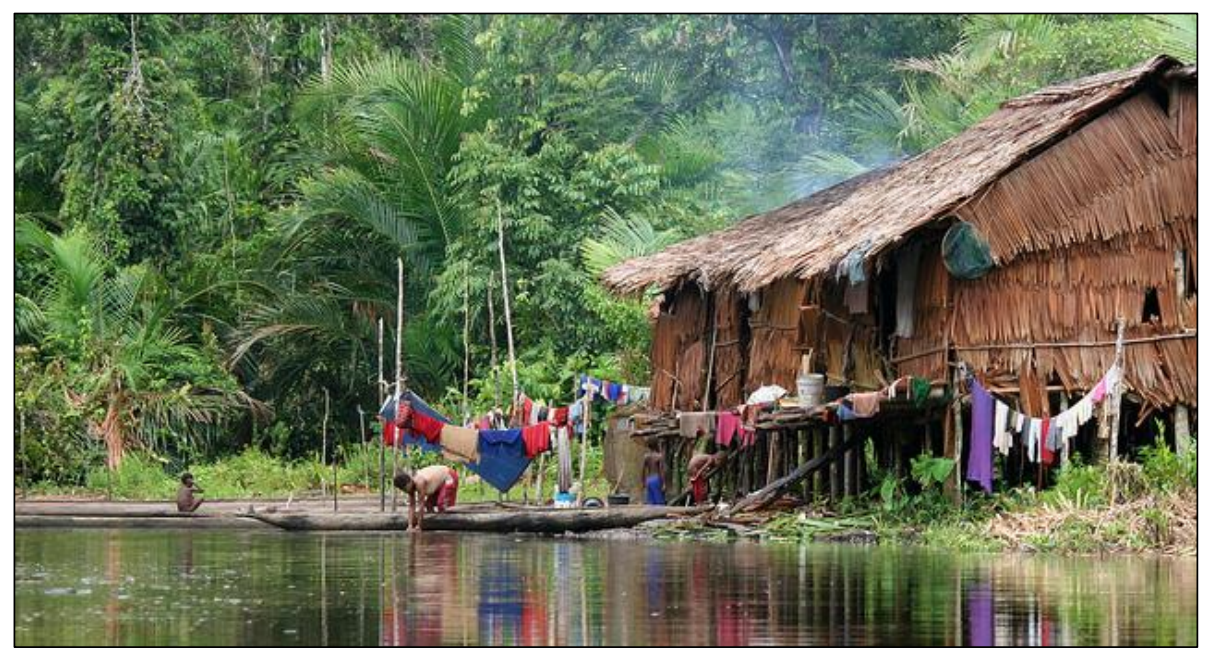

Figure 4. This Papuan Asmat village in the coastal swamps consists of one long house housing several families. The people live in and are part of nature. Photo by Marcel Silvius (Source: https://suarapapua.com/, November 27, 2017) 
growing around the swamp. Traders who mostly come from outside Papua have big capital that they can bring food and clothing from big cities like Merauke and take them to villages by engine-powered boat or speedboat.

This also occurs in the city of Agats, the capital of Asmat District, for the disbursement of village funds or Respek it will be difficult to buy fish and sago as they prefer to consume new foods that are prone to disease. If we look more closely, as stated by Father Rangga (2018), the village funds are only briefly existed in the community because afterwards it will flow back to the merchants or to the big cities where the goods were imported. Malnutrition can occur when people consume raskin or instant noodles repeatedly that instant new foods are not able to form the physical endurance of the community.

The dimension that is not less important is relatively poor health service in the Papua, especially in rural areas. My observation in several places in Papua represents the myths when the sick are taken to the Community Health Center (puskesmas), he or she will die sooner than those who are not taken to the place. This is due to expired medicines or unsterile needles and lack of health workers in the villages. This causes people in remote areas of Papua to be frightened of immunization by puskesmas. The low level of public services is exacerbated by the tradition of sedentary living for hunting. The lack of coordination of health offices in provinces, regencies, districts, and villages aggravate this condition. There are certainly many public health centers infrastructure in the capital district or sub-health centers in some villages. Nonetheless, the building is not equipped with adequate medicines and is not served by professional medical personnel. Doctors and paramedics prefer to stay in the capital district or other big cities because of the harsh environment and difficulty adapting to society. They came to the Papua partly not equipped with sufficient knowledge about the culture of tribes in Papua. Some medical personnels, even outside Papua, according to JDP-LIPI notes feel insecure due to intimidation from armed civilian groups or Papuan independence fighters that they prefer to live in cities guarded by police or army officers (LIPI, 2013). The research of Van Den Pas (2015) stated that this condition has occurred since postreformation that mortality rate of children under five in the Papua is high enough to exceed mortality rate under five in Papua New Guinea and Indonesia. Most medical personnels stay in the city and get paid with good salary without doing much work, while the building of the Puskesmas left empty is not well maintained.

The phenomenon of low public services represents that government control is absent from public services in villages. This has implications for the lack of sanctions imposed on security officers who abandoned their duties. While the medical personnels coming from the Papuan people who have quality like the immigrants are also difficult to obtain. Medical personnels recruited from Papuan villages have not received adequate training like medical personnel newcomers. In fact there are quite a lot of professional medical workers despite its unevenly distribution, they only work and settle in big cities of which good infrastructure are such as Jayapura, Sorong, Timika, Nabire, and Merauke. Inequality in the availability of medical personnels has occurred since the New Order era. In the past, before the issue of Papuan independence emerged, quite a lot of doctors or medical personnels from outside Papua who were willing to work in remote areas and live together with the community. Following the 1998 reforms, however, along with Papuan independence demands, many of these migrant medical workers were frightened of their future and safety. Limited health workers in Asmat District are now confirmed by the Minister of Health, Nila F Moeloek on February 1, 2018. According to him, from 13 Puskesmas in this area, there are only seven general practitioners and one specialist doctor. Not all health centers that are generally located in every district have general practitioners. Afterall, other medical personnels can already be deemed sufficient (Ihsanuddin, February 1, 2018).

The health care system in Tanah Papua in general and in the Asmat Regency particularly in the present is far different in its quality from that of the colonial period. If Indonesian doctors and medical personnels generally settle in community health centers and wait for patients to arrive, Dutch doctors and medical personnels pick up people in their villages and homes. According to Logowan (2017), during the period 1950-1959, the Government of the Netherlands New Guinea, especially during the era of Governor Van Baal, an Anthropologist, established a service system of village to village, house to house and person to person. The colonial government established a health team in each afdeling consisting of a Dutch physician, three to four Dutch nurses, one church

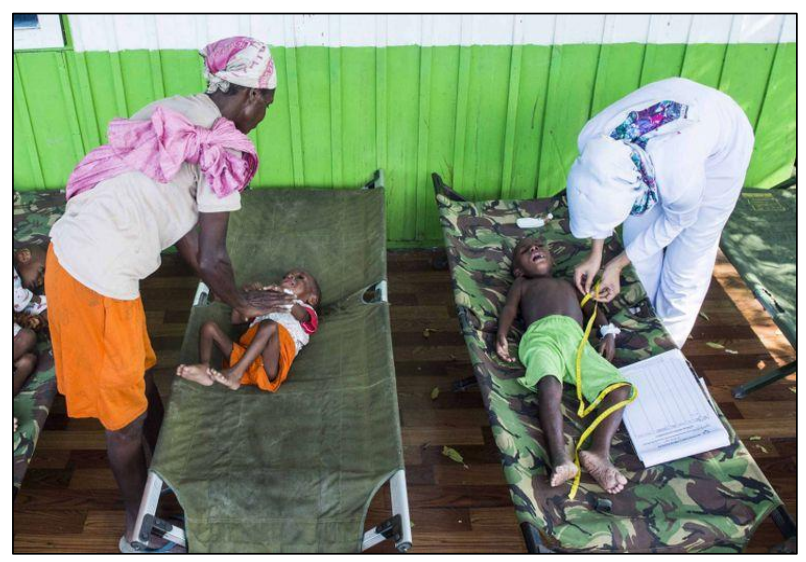

Figure 4. Health workers provide care to a number of malnourished children from Warse village, Jetsy District in RSUD Agats, Asmat District, Papua, Monday (22/1/2018) (Source: Antara Foto/M. Agung Rajasa, 2018) 
sister, and ten to fifteen local nurses, and escorted by several police officers. They walk or row a boat from capital city to the districts. From their districts, they went along the rivers and valleys to the villages. In every village, this group went to the homes of the Papuans. They checked and asked about their health conditions, identifying emerging diseases and providing health counseling. These doctors were graduated as the best doctors from the Netherlands, coming to Papua for humanitarian missions with unpaid high salaries and ignoring life in the wilds of which the population were known as cannibals in the past. This highly dedication and human spirit is rarely encountered on Indonesian doctors who claim to rule the modern world and more civilized than the Papuan people. In each village, this Dutch medical mission treated the sick, provides medication and free consultation, conducting research on infectious diseases and alternatives treatment (Lagowan, 2017).

\section{Strategy to Build Social Resilience on Asmat Tribe}

Father Neles Tebay, Papua Peace Network Coordinator, in Papua Lawyers Club (January 31, 2018) suggested that the Asmat outbreak is a series of epidemics that have occurred in Papua since two years ago. For instance, from April to July 2017, fifty children under the age of five died in Tigi, Deiyai District and from July to October 2017, 35 Papuan children died in Inikgal, Nduga District. This series of epidemics denotes that communal deaths for Papuans can occur anytime and anywhere, especially those living on the Land of Papua. In other words, Father said that Papuans' social resilience is relatively low compared to outsider communities.

It has been a tradition since the New Order era, health facilities and infrastructures, as well as education in transmigration settlements or migrants, are far more adequate than in Papuan villages. For instance, transmigration complexes in Merauke or Keerom districts, they have Community Health Center (Puskesmas) with more adequate doctors along with medical personnel and health equipment and medicines. They are also accompanied by various elementary school facilities to upper secondary level with adequate and professional faculty. This often leads to discrimination in the service of basic needs between Papuans and newcomers. In the long term, the resilience of outsider communities will be much better than the Papuans who should be masters in their own land.

If we speak of resilience, the government is not the solely institution responsible for health affairs in Papua. According to Father Neles (2018); the central, provincial and district governments have taken many steps to prevail over malnutrition and measles, but delegating all health problems merely to the government will undo the responsibilities of various other stakeholders. Having pointed out in advance, during this time, Jakarta has always considered the shortage of medical personnel, medicines, transportation costs, difficult terrain, and low awareness of Papuans to live healthy, unclean dwelling environment has always been major cause for mass death of Papuans. Father Neles stated that this cause should not always recur in the event of a mass death in the future, the solution being that Papuans must have their own ability to deal with malnutrition. Papuans should not be subjected to this cause incessantly throughout the ages. In an event at the Papua Lawyers Club on January 31, 2018, Father Neles suggested that Papuans should be able to solve this problem on their own by utilizing their social capital. They must be empowered to become volunteers who have the ability in the medical field that they are not blamed for the conditions occurring to them. In other words, Papuans should be confident that even if they live in isolated areas, they are able to take care of their health independently.

Some of the Asmat tribe communities have been victims of relocation during the New Order period as the forests where they live are exploited by the company (Abdulsalam, January 28, 2018). In its history, the Asmat lived as hunters and gatherers, utilizing the available natural wealth. Their average education level is fairly low and the geographical difficulty level is quite high as it is located in the swamp area. In the Papua Lawyers Clubs (January 31, 2018) event, Father John Jonga stated that Asmat people have long been malnourished since they were relocated from the forest to the estuary. During the reign of President Yudhoyono, raskin rice began to be distributed and made them reducing their consumption of sago. The cultural life of Asmat people is not a major obstacle to the spread of this malnutrition. They have never been planters or farmers like in other areas, but they live from the forest.

Ironically the Asmat's dwelling places in the forests have been cut down during the New Order period, including sago forests. High nutritious sago caterpillars are a major nutritional source in the past, but along with the destruction of Asmat forests, sago forests and their caterpillars also become extinct. Wild boar and cassowaries also disappeared along with the loss of the Asmat forest. Ecological damage is a major source of decline in Asmat survival. In other words, the change in the environment from the forest to the swamps in the estuary is not accompanied by the adaptability of this community that their resilience is quite vulnerable. According to the Minister for Women Empowerment and Child Protection, who came from Papua, Yohana Yembise, the dependence on rice as a staple food makes the Asmat community has no alternative source of food. As a consequence, if rice for the underprivileged (raskin) 
has not reached this area, they will find it impossible to obtain enough food. This is indicated by the limited supply of sago and sweet potatoes in Asmat regency to support the entire population (Rahadian, February 1, 2018).

Revitalizing local wisdom is one of the prerequisites for rebuilding the resilience of Asmat tribal communities that they are not dependent on the outsourced food and medical personnel. However, their way of life in the past are not all relevant to the present. For example, some of these tribal custom are also regarded as unhealthy way of life such as night out at risk for malaria and tuberculosis (Kurniawan, 2008: 67). According to Father Rangga (2018), the handling of the issue of Asmat outbreaks by various government agencies and other humanitarian organizations should be highly appreciated, but the problem solving is only short-term, thus it is necessary to figure out the strategy to revive the resilience of Asmat people in the long term both economically and socially. It is important that this case does not take place anymore in five or ten years. Father Rangga proposed that the Government and Asmat community avoid interpreting the village funds by throwing money. Abundant money tends to keep them away from the tradition of working hard. It is also necessary to revive the tradition of cultivating sago to be consumed as the main food ingredient of Asmat people, rather than raskin rice. In this case, it will establish local food security.

Rollings (2010) expressed that forest clearance in Tanah Papua began in the early 1970s when forest resources in Kalimantan and Sumatra were no longer attractive for exploitation of forest products. This was accompanied by an increase in timber exports, in the period 1979-1981, while timber exports from Papua reach 30 million USD. This has implications for the entry of investors and workers who are mostly from outside Papua. As a result, the number of tree populations and biodiversity has decreased and even damaged. This phenomenon has had a negative impact on some tribes in Papua that depend on forest for their livelihoods, including the Asmat tribe, as they live dependent on forest resources (Abdulsalam, January 28, 2018).

A human rights activist, Carmel Budiarjo (1996) pointed out that the Asmat tribe was one of the victims of environmental damage during the New Order era. According to him, members of the tribal community are forced by the security forces to work in various timber companies based in Jakarta, generally owned by high military officials and protected by local security forces. Budiarjo's record explained that the Company and the security force also relocate the Asmat tribe community from inland to the riverside which is located close to the loading place of wood. The purpose of this relocation is to make it easier to monitor the activities of the population and use them as low-cost paid labor. No wonder the Asmat region during the time was a closed area for outsiders. Environmentalists have warned that a decade of forest destruction will lead Asmat tribes on the verge of extinction as they can no longer live from the forest and will not be able to adapt to natural damage (Tirto.id, January 28, 2018).

This is another case when Asmat was managed by the Dutch colonial government. Tirto Magazine reported the following:

"Until the end of the 19th century the colonial government only infiltrated and controlled the coastal areas due to limited troop and human resources and transportation difficulties to the hinterland. Only in the early twentieth century, precisely between 1907 and 1913, the Netherlands sent expeditions to the inland of South and South West Papua including the Asmat tribal forest, led by a Dutch captain named Jan Gooszen. This expedition collected 6,616 museum objects, of which 933 objects were taken from the Asmat tribe. Gooszen's persistence eventually collapsed after in 1913 he fell ill with malaria. Further unknown expedition occurred between the years 1913 to post-war second world. The record of colonial government represented that in 19601961 an anthropologist from the University of Leiden, the Netherlands, Adrian A. Gerbrands (1967) conducted research on the work of Asmat wood carvings. He collected 599 museum objects from the Asmat tribe. Then in 1999, Dirk Smidt (1993) described a series of explorations and research on Asmat tribes conducted during the colonial period (Tirto.id, January 28, 2018)."

The appreciation of Asmat tribe in the form of recognition of cultural identity has been carried out since the New Order era. The award is symbolic, however, and the Government continues to allow the process of exploiting the lives of Asmat people at the most alarming levels. For instance, in 1873, the Museum of Asmat Development and Culture was established by the Government in Agats, it became the capital of Asmat district, Merauke regency at the time. According to Tirto's records, the museum has 2000 objects, obtained from Gunter Konrad and Toias Scheneebaum. Only in 1986, the Central Government established Asmat Museum in Taman Mini Indonesia Indah (TMII) which is an exhibition center of all cultures throughout Indonesia (Abdulsalam, January 28, 2018).

Recognition of Asmat tribe identity and culture is merely an artificial culture as the Netherlands recognizes the culture of Javanese empire but continued the process of exploitation to the wealth and people of the Dutch East Indies. Although Asmat Museum in Agats and Asmat Museum in TMII reflects affirmation of Asmat identity in Indonesian culture, but on the other side Asmat forest remains exploited by companies that cooperate with the state security forces. In fact, in 1987, according to Aditjondro (1998), Asmat Advancement and 
Development Foundation or Yayasan Kemajuan dan Pengembangan Asmat (YKPA) was founded by Mrs. Tien Soeharto and managed by General M. Kharis Suhid. Siti Hardiyati Rukmana as Deputy Chairman of the Foundation and the foundation was getting paid capital from the owners of large companies such as Kartasasmita, Ibnu Sutowo, Bakrie, and Bukaka. The foundation established the Asmat Central Building in Asmat District and promoted Asmat culture in Jakarta, Germany, France, and in 1990 in the UK. YKPA is actually a cover for covering up the Asmat forest destruction by those companies for harvesting (Aditjondro, 1998). Based on the exposure we can recognize that although the Asmat Tribe became one of symbols of recognition of the culture of minority tribes in Indonesia, but the recognition is not comparable with exploitation of Asmat Forest, that the tribe lost its resilience after three decades later. Tirto mentioned that the Asmat Tribe is the icon of multiculturalism yet also the icon of Indonesian colonialism against Papuans (Abdulsalam, January 28, 2018).

\section{Looking Forward Solutions}

In order to build social resilience of the Asmat community, many efforts are needed from various parties to support it. As mentioned earlier, many parties must be involved as stakeholders to address the issue of outbreaks in Asmat District. It is an agreement that the issue of Asmat outbreaks is not merely a health issue but a matter of food security, culture, economy and politics. In this case the government is only one of the stakeholders. Other parties to be involved include companies that exploit Papua, religious organizations, customary institutions, women's groups, and nongovernmental organizations. According to Father Neles Tebay in the Papua Lawyers Club (January 31, 2018), all parties should be able to contribute significantly to addressing malnutrition and health issues and promoting healthy living among Papuans including the Asmat tribe. Every stakeholder should be involved and engaged in handling health issues in Tanah Papua. Therefore, they should be brought together in a joint dialogue facilitated by the Government to identify health problems in Papua and how to find solutions, implement them and supervise them cooperatively. Without sharing of roles and joint participation between various stakeholders, the health issues in the Land of Papua will not be resolved. One of the media that can be used to bring together these various stakeholders is by organizing dialogue in the field of health sector attended by parties both from Jakarta and Papua. They are invited to be participants of the dialogue to find a common solution that these events are not recurring in the future.

Of a number of stakeholders, the military is most complicated issue in the region. The government has deployed several troops to deal with malnutrition in Asmat District. They are most prepared human resources and ability to navigate the rough terrain, and get used to humanitarian missions. On the one hand their presence to provide emergency relief to malnutrition victims in Asmat is indeed necessary. But conversely, the military is an icon of colonialism that fosters insecurity for some Papuans. According to Father John Djonga, Papuans generally still have bad memories of the presence of the Indonesian security forces. They had experienced trauma when Papua became a Military Operations Area (DOM). Although the Independent Papua Organization (Organisasi Papua Merdeka) was also violent against civilians, the image of perpetrators of violence is still attached to the security forces, which is the TNI-Polri. Father John recounted his experience while serving the Catholics at the border of Waris, Keerom District in 2007. Papuans were frightened in meeting the military. In fact, when they got medication from members of the TNI, they were scared to take it. This indicates that psychologically traumatic violence in the past is still a common memory, memoria passionis.

As having stated in advance that transportation is the biggest obstacle to solve the problem of Asmat at this time. Without good infrastructure, both on land and in rivers, it is unlikely that health workers can be deployed to remote villages and otherwise it is impossible for the community to reach community health centers in the capital districts, which takes hours to one day. In order to take the sick to Agats it can only be done by enginepowered boat or speedboat. Since there is only one hospital in Agats with inadequate conditions, then more adequate treatment can only be done at the nearest hospital in Timika Town. The required transportation is an aircraft within 20 minutes distance. The cost required to rent a small plane for going back and forth will be as much as 15 million rupiahs (Abdulsalam, February 1, 2018). The authors' observation indicates that the transport problem is not only found in Asmat but in most of Land of Papua that it has similar problems both living in the mountains and in coastal areas. In order to address this issue, the government may cooperate with missionary or military airlines or provide subsidies to special private flights to transport patients outside the Asmat District.

One of the main solutions of this case according to the observations of most central officials is by overseeing the government's budget to achieve its goals. According to the chairman of the House of Representatives of The Republic of Indonesia, Bambang Soesatyo, Asmat outbreak (KLB) is a proof of ineffectiveness of the Special Autonomy fund to meet the basic needs of the people of Papua as the amount of Otsus funds does not automatically improve the welfare of Papuans. Although the allocation of Otsus funds for 
the health sector allocated to Asmat District reaches 60 billion rupiah, in order to finance the Papuan Health Card and health operational costs, but it has not been able to finance all the handling of malnutrition in the area. Total Otsus fund for Papua Province in 2018 is 5.6 Trillion and West Papua Province is 2.4 Trillion Rupiah. While infrastructure funds are 2.4 and 1.6 trillion rupiah for the two provinces. The head of the Papua Provincial Health Office, Alosius Giyai, stated that the Otsus fund was unsatisfactory as there were still many children under five who died from measles and malnutrition in some districts in Tanah Papua (Apinino, January 31, 2018).

Some causes of ineffectiveness of Otsus Fund include the poor government capacity and civil control (Trijono, 2007). The Special Autonomy Fund should be thoroughly evaluated, especially with regard to achievements and failures and the causing factors that have failed to achieve its targets, especially in the areas of health, education, economy, people, Papuan affirmations and infrastructure. This is necessary as the problems in Papua are interdependent with one another, therefore they must be resolved comprehensively. If we explore further, the central government expressed that they have evaluated the implementation of Special Autonomy, but the results of its evaluation have never been made public. The same was done by financial auditing agencies such as BPK and BPKP, as their results have never been followed up with consideration of maintaining political and security stability in these two provinces. For instance, the findings of BPK in 2011 mentioned that there was an impropriety of the handling of Otsus funds as much as 2.5 trillion rupiahs in the period 2002 to 2011. Indeed there have been some regents who were arrested for corruption cases, but the arrest did not bring a deterrent effect for improving governance in the Government of Papua.

However, we need to beware that the case of Papua is not solely the issue of the Special Autonomy Fund (Otsus). To this point, the government only executes Otsus by sending large funds, but the implementation of the Special Autonomy Law has never been seriously taken into account. For the intellectual elite of Papua, Otsus has failed and emerged the discourse of Otsus return and the formulation of the Draft Law (RUU) of Otsus plus. Other aspects that must be considered yet often ignored are issues of historical alignment, protection of human rights and indigenous peoples and the use of cultural symbols as mandated by the Special Autonomy Law. There is also a problem of failed development in Papua due to the distrust of Papuans towards the Central Government and stigmatization of the Central Government towards Papuans who wish for independence. Widjojo (2008) mentioned that the elimination of stigmatization will increase mutual trust between the community and the government which ultimately can improve implementation of development in the education, health and economic sectors.

Approach in development of Land of Papua is the main keyword. Asmat outbreak (KLB) is a phenomenon of iceberg, which can be found in some areas of Papua. The main problem according to Father John is that the government has not been aware of what Papuans yearn for. Father said that whatever is built and what the people of Papua wish for is often inconsistent. Although tens of trillions are provided to the Government of Papua and West Papua, yet the approach against Papuans is mistaken, the development will not work (Abdulsalam, February 1, 2018). If the relocation plan of the Central Government which has been rejected by the Governor of Papua and Asmat Regent is forced to run, the result will not be optimal as the Asmat community depends on the forest and cannot be uprooted from its ecological habitat. The way out of difficulties in reaching isolated areas should be sought after, but it cannot be done by relocating the population. Based on the experience of medical personnel during the Dutch period as described above, the best solution is to make the health unit close to the people in the villages.

Geographical isolation and transportation difficulties are not an obstacle in bringing health services closer to the patient by reaching them. A doctor as member of the Fast Action Response (Aksi Cepat Tanggap) team sent to Agats, Asmat District recollected of his experience in doing service to Asmat. He took his journey from Merauke to Agats, the capital of Asmat District reached by boat sailing along the Arafura Sea. Having arrived at Asmat, they distributed nutritious food supplies for children. Afterward, they did counseling about nutrition and preparing medical services. On the first day of medical service, they moved along the rivers to reach districts and villages using engine-powered boats. In Agats and Asmat villages, there are no road infrastructures such as in Java, but only wooden planks as the main road from one house to another. The wooden planks are arranged to form a small path over swamps or rivers. This makes Kampung Agats known as districts on wooden boards.

Transportation is the most complicated challenge for Asmat residents. The length of the journey from one village to the next ones by engine-powered boats reaches two to three hours. For instance, from Agats to the village of Ambisu, Atsi district, located on the edge of the Arafura Sea. Once arrived there, the team gets Ambisu Auxiliary Community Health Center. There are many children found who suffer from measles and malnutrition, higher body temperature, very thin body to the protruding ribs. Finally, with the examination and health care of the team, some children have decreased their body temperature and can be well-treated. Following more in-depth study based on the condition of 
the children in this village, malnutrition in this area can be categorized into the marasmic type that is the worst condition of malnutrition in children and infants, characterized by: sunken and wrinkled eyes, dry mouth, protruding ribs due to depletion of fat. Malnutrition is a disease that can be prevented by the Government and various parties by providing calories and nutrients to children and infants through provision of healthy foods (Amanda, January 28, 2018).

In order to respond to malnutrition and measles diseases, the Government has set up a special task force to handle them by involving various ministries and agencies. The Papua Provincial Government established a barefoot task force to reach the Asmat areas. It is wellrealized that although the aid cannot all be distributed equally, the Government is striving for health issues in Land of Papua, such as immunization of 13,300 children in Agats, capital of Asmat Regency (Rahadian, January 31, 2018). The phenomenon described above indicates that the issue of Asmat outbreak (KLB) has already been in chronic stage and the solution is not only management of health issues but restoring the resilience of the Asmat tribe in order to survive in the future.

\section{CONCLUSION}

Based on the explanation described above, it can be concluded several things as follows:

First, the representation of malnutrition in Asmat District has been consequently severe that it threatens the sustainability of Asmat life. In addition, this extraordinary event (KLB) is also a phenomenon that almost occurs throughout the Land of Papua both in mountains and coastal areas. Not only the Asmat, but the future sustainability of the Papuans is also questioned as they have no capacity to survive in rapid social change. This is different case from the outsider communities in this area that have relatively more adequate resilience.

Second, the strategy of building social resilience of Asmat People in particular and Papuans generally is the keyword to save the future of Papuans. This can be done by combining the approach of modernity that has been carried out by the cultural approach. In this context, development based on Papuan culture should be put forward. For instance, infrastructure development and corporate investment should not damage the ecological habitat of Papuans. Resilience sourced from local food production is a measure that should be encouraged to foster social resilience of Asmat Tribe.

Third, concrete solution that the government can make in the short term is to take immediate action such as a mobile health system that has been practiced in the colonial period. Medical personnels and the equipment must move and be moved to approach the Papuans instead of waiting for them to arrive. This can be materialized by a hospital ship, river ambulance, or a flying ambulance. In the medium term, sectoral dialogue involving all stakeholders is needed that they can contribute in saving the life of Asmat Tribe.

This article confirms that the social resilience of a community as described in the relevant ecological and cultural approach is used to analyze the problem of malnutrition and measles of children under five in Papua. In a theoretical perspective, the resilience of the Asmat Community has been weakened when they are deprived of two things. First, from its habitat when they are relocated by the company from the inland to the estuary. This makes them restricted in hunting, in addition to the excessive exploitation of wood by companies, and also keeps them out of their habitat. Second, the culture of instant food consumption as a result of the external dependent development model makes them uprooted from their cultural roots. In the future, a joint effort of all stakeholders in Asmat and other areas of Papua are required to revitalize the Melanesian tribal culture. Indigenous way of life and civilizations of Papuans cannot be forced to follow the process towards modernity like other Indonesians as they already have their own distinctive knowledge and cultural system of Papua, which is communal and dependent on forests.

\section{ACKNOWLEDGEMENT}

The author expresses his gratitude to all parties involved in this research. The author is also grateful for the assistance of the Kapata Archaeological Editorial Board who has been in the process of publishing until this article was published.

$$
* * * * *
$$

\section{REFERENCES}

Abdulsalam, H. (2018, January 28). Mengeksploitasi Asmat: Hutan, Budaya, dan Akhirnya Gizi Buruk. Retrieved February 5, 2018, from https://tirto.id/

Abdulsalam, H. (2018, February 1). Pastor John Jonga: Negara Indonesia Tidak Adil terhadap Orang Papua. Retrieved February 6, 2018, from https://tirto.id/

Adger, W. N. (2000). Social and Ecological Resilience: are They Related?. Progress in human geography, 24(3), 347-364.

Aditjondro, G.J. (1998). Harta Jarahan Harto. Jakarta: Pustaka Demokrasi.

Amanda, G. (2018, January 28). Kisah dokter ACT yang Singgah di Kampung Seribu Papan. Retrieved from http://www.republika.co.id/.

Apinino, R. (2018, January 31). Gizi Buruk di Asmat Cermin Kegagalan Dana Otsus Papua. Retrieved February 5, 2018, from https://tirto.id/

Asmaradani, D. (2007). Perubahan Fungsi dan Bentuk Seni Pahat, Seni Patung Suku Asmatdi Papua Sebagai Produk Kerajinan. Jurnal Dimensi Seni Rupa dan Desain, 5(1), $1-14$. 
Barth, F. (1969). Ethnic group and boundaries: The social orgnanization of cultural difference. Oslo: Universitetsforlaget.

Bishop, B. J., \& Syme, G. J. (1996). Social Change in Rural Settings: Lessons for Community Change Agents. In D. Thomas, \& A. Veno (Eds.), Community Psychology and Social Change (Second Edition) (pp. 157-180). Palmerston North: Dunmore Press.

Budiarjo, C. (1996). Surviving Indonesian's Gulag: A Western Woman Tells Her Story. London: Cassell.

Budisantosa, S., Hidayah, Z., Rumbiak, M. D. E. (1986). Masyarakat dan Kebudayaan Asmat. Proyek Inventarisasi dan Dokumentasi Kebudayaan Daerah Irian Jaya.

Chaskin, R., Brown P., Venkatesh, S., \& Vidal, A. (2001). Building Community Capacity. New York: Aldine de Gruyter.

Eskak, E. (2016). Bambu Ater (Gigantochloa Atter) Sebagai Bahan Substitusi Kayu Pada Ukiran Asmat. Dinamika Kerajinan dan Batik, 33(1), 55-66.

Gerbrands, A. A. (1967). Wow-Ipits: Eight Asmat Woodcarvers of New Guinea. Berlin: Walter de Gruyter.

Gunnestad, A. (2003). Resilience - a new approach to children at risk in the Southern African Situation. In A. Gunnestad (Ed.), Children's Rights in Early Childhood Education in Africa and Norway (pp. 45-59). Trondheim: Network for Preschool Teacher Training and Preschool Development in Southern Africa.

Gunnestad, A. (2006). Resilience in a Cross-Cultural Perspective: How resilience is generated in different cultures. Journal of intercultural communication, 11(1).

Hidayah, Z. (2015). Ensiklopedi Suku Bangsa di Indonesia. Jakarta: Obor.

Ihsanuddin. (2018, January 23). Jokowi Panggil Gubernur Papua, Bupati Asmat dan Bupati Nduga ke Istana. Retrieved January 23, 2018, from http://nasional.kompas.com/

Ihsanuddin. (2018, February 1). Menkes Akui Dokter Tak Bisa Menetap Lama di Asmat. Retrieved February 1, 2018, from http://nasional.kompas.com/

International Coalition for West Papua. (2017). Human Rights in West Papua 2017. Wuppertal: ICP.

Jaringan Damai Papua. (2014). Jaringan Papua Tanah Damai versi Masyarakat Papua. Jayapura: JDP.

Kamun, K., Ritohardoyo, \& Santosa, L. W. (2010). Kajian Potensi Air Rawa dan Kearifan Lokal sebagai Dasar Pengelolaan Air Rawa Yomoth sebagai Sumber Air Bersih di Distrik Agats Kabupaten Asmat Provinsi Papua. Majalah Geografi Indonesia, 24(2), 157-173.

Keck, M., \& Sakdapolrak, P. (2013). What is social resilience? Lessons learned and ways forward. Erdkunde, 67(1), 519.

Kirmayer, L. J., Sehdev, M., Whitley, R., Dandeneau, S. F., \& Isaac, C. (2009). Community Resilience: Models, Metaphors, and Measures. International Journal of Indigenous Health, 5(1), 62-117.

Kurniawan, J. (2008). Analisis Faktor Risiko Lingkungan dan Perilaku Penduduk terhadap Kejadian Malaria di Kabupaten Asmat Tahun 2008. Thesis Universitas Diponegoro.

Lagowan, B. (2017, November 7). Upaya Belanda Membangun Kesehatan Papua Bagian 3. Retrieved from https://suarapapua.com/

LIPI. (2013). Laporan Pertemuan Eksploratif di Lombok. LIPI, August 23-25, 2013.

Maryone, R. (2011). Totemisme pada budaya Asmat. Papua, Jurnal Penelitian Arkeologi Papua dan Papua Barat, $3(1), 51-63$

Narrol, R. (1964). On Ethnic Unit Classification. Current Anthropology, 5(4), 283-291.
Papua Lawyers Club. (2018, January 31). Diskusi Terfokus tentang Penanggulangan Kejadian Luar Biasa Asmat. Diselenggarakan oleh Jaya TV dan Jaringan Damai Papua di Hotel Aston Jayapura.

Prasetya, L. E. (2013). Budaya Lokal sebagai Potensi dalam Pengembangan Kawasan Ekonomi Khusus (KEK) Kabupaten Asmat. In Proceeding Simposium Nasional RAPI XII - 2013. Solo: Fakultas Teknik Universitas Muhammadiyah.

Purba, J. R. (2018, January 15). 4 Bulan 61 Anak Meninggal akibat Campak dan Gizi Buruk, Ini Kata Bupati Asmat. Retrieved January 15, 2018, from https://regional.kompas.com/

Puspita, R. (2018, January 29). Menkes: KLB di Asmat Akibat Beragam Masalah. Retrieved from http://nasional.republika.co.id/

Rahadian, L. (2018, January 31). Pemerintah bentuk satgas atasi campak dan gizi buruk di Papua. Retrieved February 5, 2018, from https://tirto.id/

Rahadian, L. (2018, February 1). Menteri Yohana: Warga Asmat Tergantung Beras dan Stok Sagu Minim. Retrieved February 5, 2018, from https://tirto.id/

Rahajaan, J. D. (2012). Tinjauan Simbol sebagai Alat Komunikasi Ritual Suku Asmat. Jurnal Seni Rupa dan Desain, 3(12), 18-22.

Rahawarin, Y. Y., Kerepea, Y., Mofu, W. Y., Angrianto, R., Peday. H. F. Z., Sinery, A. S., \& Dimara, P. A. (2014). Perburuan Kasuari (casuarius spp.) secara Tradisional oleh Masyarakat Suku Nduga di Distrik Sawaerma Kabupaten Asmat. Jurnal Manusia dan Lingkungan, 21(1), 98-105.

Rangga, A. (2018, February 1). Melihat KLB Asmat dari Dekat. Retrieved February 5, 2018, from http://www.dawainusa.com/

Rollings, L. B. (2010). The West Papua Dilemma. Thesis University of Wolongong.

Smidt, D. A. (1993). Asmat Art: Woodcarvings of Southwest New Guinea. Leiden: George Braziller in association with Rijksmuseum voor Volkenkunde

Sonn, C., \& Fisher, A. (1998). Sense of Community: Community resilient responses to oppression and change. Journal of Community Psychology, 26(5), 457-472.

Tebay, N. (2018, January 16). Masalah Kesehatan Tanggung Jawab Bersama. Retrieved February 5, 2018, from https://www.pasificpos.com/

Trijono, L. (2007). Pembangunan sebagai Perdamaian: rekonstruksi Indonesia pasca-konflik. Jakarta: Yayasan Obor Indonesia.

Vaessen, S. (2018, January 27). The hollow eyes of hunger in Indonesia's Papua. Retrieved February 5, 2018, from http://www.aljazeera.com/

Van de Pas, R. (2015). Health Care in West Papua. International Conference: Papuans in West Papua Depopulation, Health Care \& Education. Brussel.

Widjojo, M. S., Elisabeth, A., Dewi, R., Al-Rahab, A., \& Pamungkas, C. (2008). Papua Road Map: Negotiating the Past, Improving the Present, and Securing the Future. Jakarta: Pustaka Obor.

\section{Footnotes}

i. Submitted by Alosius Giay, Head of the Provincial Health Office of Papua, in the event of Papua Lawyers Club Jaya TV and the Papua Peace Network on January 31, 2018 in Jayapura. 